\title{
Ideational Meaning: Media Representations of Sino-Bangladesh Relation and Its Actors
}

\author{
Muhammad Anisur Rahman Akanda* \\ School of Foreign Languages, Shanghai University, 99 Shangda Road, Shanghai, 200436, P. R. China
}

\begin{abstract}
This study, within the frameworks of Systemic Functional Grammar and Critical Discourse Analysis, aims to explore how Bangladesh's news agency BSS (1975-2016) represents Sino-Bangladesh relations. Three methods are employed to collect the data: (i) the 40 year media coverage, (ii) questionnaire and (iii) observations at the newsrooms. By examining 140 news reports and investigating linguistic features, this study shows how the BSS under government control represents China and Sino-Bangladesh relations. This study will focus only on the analysis of the news headline as a 'micro story', while the news body is completely excluded from the analysis. The findings will show how the social actors are constructed through the BSS media discourse on the topic. This study will detail the representations of the actors at the clause as a representation. The main reason for historical change is the establishment of the diplomatic ties between Bangladesh and China in 1975. This paper clearly explains how the media representation generally reflects social practice, ideology and power relations in social structures at the time of reporting.
\end{abstract}

Keywords: critical discourse analysis, systemic functional grammar, Sino-Bangladesh relation, BSS media discourse, representation

DOI: $10.7176 /$ JLLL/52-11

\section{Background of the Research}

The critical discourse analysis approach applied to analyze language use on the topic of Sino-Bangladesh relations must fit the proposed research. Frantz $(2006$, p. 2) explained that traditional linguistic approaches have their own domains. The early studies focused on the systems of language analysis during the last 100 years as linguistics has become a scientific discipline for applying methods of empirical and historical investigations. In this context, meaning is generally considered a core concept to the study of applied linguistics. Bloomfield (1933), for example, argued that meaning was so messy that it was impossible to define linguistic meaning in analyzing grammar. Chomsky $(1957,1965)$ advocated that the best method of analyzing grammar was through formal learning. Both believed meaning was relevant to linguistic analysis, although it could theoretically be isolated from specific instances of language use (Chomsky, 1957). Social scholars (Gramsci, 1971; Foucault, 1972; Habermas, 1984; Hall 1985) have demonstrated that social and political power may be created by, reflected in, and resisted through language use. A second generation of discourse analysis developed the main ideas of Michel Foucault, focusing on the relation between power and knowledge (Foucault, 1980). Critical discourse analysis (CDA) was finally generated through the works of Fairclough (1989), Wodak (1989) and Van Dijk (1993). An examination of the roles of actors over the social practices can be an important analytical tool for CDA (Fairclough, 2003, p. 17). Discourse is responsible for the construction of our social realities (Foucault, 1972, p. 215). Truth represents truth and regulates discourse (Foucault, 1980, p. 131). Truth endorses certain ideas while rejecting others. This is called the critical discourse analysis to the common sense assumptions which often go unquestioned because they are believed to represent truth and reality (Fairclough, 2001, p. 77). Recently, new dimensions have emerged from interconnection between critical linguistics (CL) and critical discourse analysis (CDA) in the field of applied linguistics. $C D A$ is mainly concerned with the relationship between language, ideology and power (Fairclough, 1989, 1992, 1995a). Within the last four decades, theoretical linguistics (sociolinguistics, psycholinguistics, discourse analysis) have maintained a common connection of analyzing language use scientifically. The analysis requires two main things against traditional linguistics. First, analysis must focus on situated meanings. Second, it requires the interpretations of situated meanings. The question of the relationships among society, culture and language is a highly complex question related to Williams (1981). Human beings are reflexive; there is always a dialectical interconnection between what they do and how they represent (Fairclough, 2003, pp. 18-23). Cultural systems help clarify the relationship between culture and language. Cultures are not only discourses but also systems of consciousness. CDA is especially suited to the study of media discourse (van Dijk, 1993, p. 249; Fairclough, 1995b, p. 2). For example, Zhang (2014, p. 2273) examined the political news reports between the context of American and Iraq including The New York Times utilizing Fairclough's framework. As a resource of discourse, I shall analyze the BSS media discourse of Sino-Bangladesh relations. CDA is a branch of discourse analysis that highlights cultural and ideological meaning of the media representations asking the questions: (i) What changes have taken place during the period of the relations between discourse change and change in the relationship between Bangladesh and China by the BSS media discourse (1975-2016)?; (ii) How are social subjects and their actions represented 
through use of grammar, text, and discourse practice? The BSS was chosen because of its 40 year international news coverage, which must necessarily uncover the complexity of Sino-Bangladesh relations. The main objective is to explore how language is used to express meaning. The findings show how the results might affect theory and practice in this field. This is the background of this study falling into five parts. Part two discusses historical and political contexts. Part three examines data collection and its framework. Part four is the central part, which focuses on the media representations of Sino-Bangladesh relation and its actors. Part five, conclusion, summarizes the main findings, including implications, limitations and suggestions for further research.

\section{Historical and Political Contexts}

This category aims to explore the early historical and empirical reviews of Sino-Bangladesh relations because of many reasons. China rises dramatically in modern world, which will tomorrow's biggest power that influences all countries including Bangladesh (Ministry of Information, 2017). The Rise of China has become a great factor into the regional discourse (Chandra, 2015, p. 220). China's rise needs to be studied by all Asian countries for two reasons: One is led by India, and the other by almost all other countries. It was during the 1970s that early projects were taken to explore the possibility of regional cooperation by the European funding agencies (UNDP, ADB) for undertaking research (Chandra, 2015, p. 182). As an old Chinese saying goes, we can always get a better understanding of the present by reviewing the past (BD-China Embassy, 2017). With this aim, I look back into the early history of Sino-Bangladesh relations through the Silk Roads connecting China and this region (Bangladesh, 1988; Xianyi, 2010; Keay, 2011). In ancient times, the Silk Roads were a meeting place of world cultures and religions, first for Buddhism and later for Islam (Allan, 2013, p. 145). Many Chinese scholars believe that the Southern Maritime Silk Road was the earliest link between China and the Indian subcontinent. The Silk Road was an original passage through which, some minorities in Bangladesh came from Sichuan, Yunnan, Tibet and Mongolia (Uddin, 2013, p. 230). In the early 21th century, Xi Jinping, the President of China wants to revive the ancient Silk Road linking China with Asia, Africa and Europe (Islam \& Askari, 2015, pp. 1823). It marks the return of a legend with historical and linguistic references to "yi dai yi lu," (a belt, a road). It is a gigantic project covering about 60 countries and half of population in the world. In an ideal scenario, the new Silk Road can become the biggest economic trade route since the Marshall Plan, with which the United States helped Germany get back on its feet after the Second World War. The Western media (AFP, May 15, 2017) reports asking the question: What is Beijing trying to achieve with its Silk Road plan? The most advanced countries (China, India, Brazil, Russia and South Africa) are advocating for south to south cooperation as the Rise of India and China (Roca, 2013, p. 164). However, this study considers only two countries, Bangladesh and China; both have many problems in the 21th century (Yasinbin, 2012, p. 3; Sarker, 2014, p. 83). The main problem is the language barrier and climate change is one of the biggest threats to both countries and both need to share their lessons (CASSLD, 2013, p. 3). In 1971 China did not support Bengali nationalism during the War of Independence due to close relations with India, USSR and China-Pakistan-US alliance (CASSLD, 2013, p. 34). In 1972 China used its veto power against Bangladesh's UN membership (Datta, 2008; Singh, 2010). China stopped opposing UN membership after the treaty was signed among Bangladesh, Pakistan and India on 28 April 1974. China officially recognized Bangladesh in the United Nations on 31 August 1975. The last four decades was a critical period for China at various levels, with whom, Bangladesh is going ahead with the spirit of the modern diplomatic ties termed as 'old tested friendship', started in the October 1975, a great reflection and broadly defined as a "time-tested, all weather friendship" (China Brief, 2009, p. 10). Their relations must develop even more, although the World agencies (AP, AFP and Reuters) dominate the national agencies such as BSS (Bangladesh Sangbad Sangstha) (Bell 1991 p. 48, Glass 2001 p. 232). Reuters (founded in 1851) is one of the oldest news agencies in the world, had its branches in different parts of British India (UNESCO, 1953, p. 11). The Associated Press of Pakistan (APP, founded in 1949) was turned to the Bangladesh Sangbad Sangstha (BSS, 1972) connecting with the World agencies, which have representations in the shape of stringers (Ministry of Information, 2008, p. 471). Therefore, the BSS plays a significant role with its 40 year international news coverage towards the topic of "Sino-Bangladesh relations" though it is a field of political science and global studies. A few books written by Bangladeshi and Indian scholars in English, have adopted the realist approach to study Sino-Bangladesh relations (Begum, 2015, p. 358). It is politically related with the term, International Relations (IR) from the time of the Greek historian Thucydides, the father of political philosophy (Cochrane, 1929, p. 179). Bangladeshi scholars (Rashid, 2010; Pandey, 2013; Parlene, 2013) discussed about South Asian countries' economic relations with China, while Bangladesh relations were discussed with India, Pakistan, US (United States), USSR (Union of Soviet Socialist Republics), China, and the Muslim World at the dawn of the 21st century. Application of the CDA on language use has been neglected in the country for a long time. Therefore, this study will investigate into the BSS media language use of Sino-Bangladesh relations.

\section{Data Collection \& Theoretical Framework}

The data corpus for this study consists of 140 front-page news reports focusing on the "Sino-Bangladesh 
relations" that appeared in the BSS during the periods (1975-2016). The BSS is only the government owned agency, which directly receives foreign news through satellite from the world agencies and domestic news from its branch offices. The news, which are collected and edited by a group of professional journalists, are regularly distributed primarily to the government offices, print and electronic media and secondly to the regional and world agencies (Ministry of Information, 2017, p. 343). However, I started collecting data from the BSS in June 2017. After primary analysis, 140 news reports are classified as "Sino-Bangladesh relations" in the text itself on attribution of news stories (Bell, 1999, p. 244). In gathering theoretical studies, 177 related studies were downloaded from the ProQuest database and Google Scholar. Only 79 studies applying CDA approaches were included and organized under two main approaches. My first approach is Halliday's (1994, p. 30) Systemic Functional Linguistics, which clearly interprets three definitions as psychological Subject (Theme), grammatical Subject (Subject) and logical Subject (Actor). This is believed that Subject, Actor and Theme function at three distinct clauses: (i) The 'Theme' functions in the structure of the clause as a message; (ii) the 'Subject' functions in the structure of the clause as an exchange; and (iii) the 'Actor' functions in the structure of the clause as a representation. As Halliday (1994) suggests, "Three headings refer to the transitivity system that enables human beings to build a mental picture of their reality" (108). This study focuses only on the structure of the clause as a representation, while the other structures are excluded from the analysis. My second approach adopts Fairclough's (1995a, p. 15) critical discourse analysis to analyze situated meanings in the context of social change. Fairclough $(1995$ a, 39) defined institutional subjects as 'social subjects', which occupy subject positions in a variety of institutions. Three models (text, discourse practice, social practice) can contribute to the representations of social subjects, social actions and relations (98). As Malinowski (1923) points out, "The analysis may refer to the context of situation, institutional context, and context of culture". Fairclough (1995b, p. 3) also advocated media discourse, which influences social subjects and their actions. Therefore, I shall analyze the BSS media discourse using Fairclough's framework associated with Halliday's Systemic Functional Grammar, the best tool for examining "linguistic and ideological meanings" (Bell \& Garrett, 1998, p. 18; Fowler, 1994, p. 39). This study aims to discuss the media representations of Sino-Bangladesh relations linking between discourse, ideology and power.

\section{Media Representations of Sino-Bangladesh Relation and its Actors}

This category aims to explore the historical changes of Sino-Bangladesh relations for two main reasons. First, analysis focuses on the situated meanings defined by the context of situation. Second, it focuses on the interpretations of situated meanings using Halliday's systemic functional linguistics.

\subsection{Situated Meaning}

This subcategory aims to define the situated meanings of Sino-Bangladesh relations asking the first question: What changes have taken place during the period of the relations between discourse change and change in the relationship between Bangladesh and China (1975-2016)? The establishment of Sino-Bangladesh relations in the October 1975 is widely seen as a great reflection in both countries (Ahmed, 2013, p. 275). Since then, the bilateral relations between Bangladesh and China have been growing very rapidly. Both countries started to exchange students since 1976. Major General Ziaur Rahman visited China in 1977 with a view to sign various agreements. The scientific and technological agreement was signed in March 1978 and a cultural agreement in November 1979. During the periods (1983-2015) both countries have had 70 Memoranda of Understanding (MOUs) (Ministry of Foreign Affairs, 2017). In 1983, Bangladesh and China established the joint economic commission. In 1986, Bangladesh provided funds to build the first primary school in Beijing with the name of Sino-Bangladesh friendship school. In 1989, an agreement was concluded on the mutual exemption of visas. In 1990, an MOU of bilateral consultations was held between two countries. In 2002, ten agreements included the construction of the $6^{\text {th }}$ BD-China friendship bridge, the development of Khulna power plant, the Barapukuria power plant, the Pagla water treatment plant and the North Dhaka sewerage treatment plant, the Dhaleswari River, military and cultural agreements. In 2003, three agreements included the construction of the BD-China friendship center, economic and cultural agreements. In 2005, fourteen agreements enclosed training for people, a concessional loan by China to Bangladesh, five MOUs of agriculture, digital telephone exchange, natural gas, water resources, the Barapukuria coal mine, an Exchange of Letter for flood control, public security, nuclear energy, group travel and friendship city. In 2005, Bangladesh and China agreed to start a direct air route between Dhaka and Beijing through Myanmar. In 2006, China submitted a report to the United Nations for its exports and imports of major arms for Bangladesh. In 2008, five agreements included three MOUs for the construction of the BD-China friendship conference centre, the Brahmaputra River, agricultural and cultural agreements. In 2009, four agreements included an MOU of joint agricultural research, the confirmation of the 'Shanghai Expo 2010, two Letters of Exchange for the constructions of the Kazirtek Bridge and the rural schools. In 2010, ten agreements included the Shahjalal Fertilizer, the $7^{\text {th }}$ BD-China friendship bridge and three Bailey bridges as well as five MOUs with Yunnan Government in education, tourism, power plant, agriculture and natural resources. In 
2011, a contract was signed on the introduction of $3 \mathrm{G}$ network in Bangladesh. In 2012, four agreements included the construction of the 7th BD-China friendship bridge, the Shahjalal Fertilizer and the Padma water treatment plant. In 2013, a loan agreement was concluded between Bangladesh and China. In 2014, seven agreements included an MOU of joint economic zone, an MOU of the construction of multilane road tunnel under the Karnaphuli River, two Letters of Exchange for natural calamity, flood control, cultural, economic and joint venture. In 2015, seven agreements related to five MOUs of education and mass media, an exchange of notes for the equipment and an agreement of 705 million USD for the Multilane Tunnel Project. Due to the better diplomatic ties, many high level state visits have exchanged visits each other during the last 40 years. For an instance, President Xi Jinping paid a two day official visit to Bangladesh on 14 October 2016. On the other hands, Prime Minister Sheikh Hasina attended the second China-South Asia Expo at Kunming on 4 June 2014. Up to now the joint committee has had 12 meetings, 35 visits including 207 persons in different fields during the periods (1984-2016). China, India, Myanmar and Bangladesh were the active participants in a meeting on February 6-7, 2002. China wants to make a common economic grid circling Myanmar, Thailand, and India using its Yunnan province. Bangladesh and China have the prospect to build the $900 \mathrm{~km}$ Kunming-Chittagong Highway through Myanmar (Ahmed, 2013, p. 279; Sarker, 2014, p. 83). Since Bangladesh and China are facing trade imbalance, China gave zero-tariff treatment to 4,762 products from Bangladesh on July1, 2010. Both countries have also had a number of Memoranda of Understanding (MOUs) addressing climate change (Ministry of Foreign Affairs, 2017, p. 3). Adopting a look east foreign policy, therefore, the Sino-Bangladesh relation is termed as a symbol of 'old trusted friendship'.

\subsection{Interpretation of Situated Meaning}

This subcategory aims to interpret the situated meanings using Halliday's transitivity system that looks at how meaning is represented through the news headlines of Sino-Bangladesh relations, asking the second question: How are social subjects and their actions represented through use of grammar, text and discourse practice? As Halliday (1994, p. 15) points out, "Transitivity system is a network of systems for making meanings." The system shows how language users build a mental picture of their reality that consists of outer and inner experiences. The outer experience is the process of the external world, while the inner experience is the process of consciousness (107). The process of the external world is called Material process while the process of consciousness is called mental process. With these two processes, there is a third type of process called Relation process. On the borderline between Material and Mental processes are the Behavioural processes. On another borderline between Mental and Relational is that of Verbal processes. On the borderline between Relational and Material are that of Existential, of all are simply recognized to transitivity system. Halliday (1994, p. 108) suggests three components: the process itself, which is expressed in its verb phrase; the participant, which is typically realized in its noun phrase; and the circumstance, which is usually expressed in its adverbial or prepositional phrase. Transitivity expresses the representational meaning of the clause with participant and circumstance. Using systemic functional view of language, the transitive structure can include the main processes summarized in Table 1.

Table 1: Process Types of Systemic Functional Grammar

\begin{tabular}{|l|l|}
\hline Process types & Examples \\
\hline Material & Chairman Mao meets Major General Ziaur Rahman \\
\hline Behavioral & Bangladesh, China signs six instruments \\
\hline Mental & Minister praises PRC assistance to army \\
\hline Verbal & Outgoing Dacca Envoy talks with PRC leader \\
\hline Relational & New development [is] in China-Bangladesh relations \\
\hline Existential & China [is] to remain beside Bangladesh: Wang \\
\hline
\end{tabular}

The Critical Discourse Analysis (CDA) adopts transitivity system as a semantic system on the idea by a clause about the world in which an action, situation and relation are predicted by the participants in language use. As Fairclough (1992) points out, "Transitivity analysis offers insights into social, cultural and ideological factors that may influence how a process is signified linguistically in a particular text." To explore the construction of social subjects in the BSS discourse, I first look at the clause as a representation of how ideologies are constructed in the front-page news headlines, which generally summarize the news contents termed as a "micro story" and "tap \& tag" (van Dijk, 1988, p. 226; Bell, 1991, p. 185). To analyze the transitivity in the headlines, I collected 140 news stories on Sino-Bangladesh relations from the BSS (19752016). This study has focused only on the Material, Mental and Relational processes, while the other processes are completely excluded from the analysis as there is no priority of one process over another. Table (2) summarizes 54 Material processes using the roles of participants and processes developed by Halliday (1994, p. 108). This assumption is related to the representations of the power and semantic relations in the "who does what to whom" of the Indo-European language families (Robert, 1987, p. 11). Table (2) shows choice in texts with 38 actors and 16 goals appearing in the subject positions. Most of the actions and situations that involve China are 
realized as actors in active structures whereas those of Bangladesh are expressed as goals in passive structures. In doing so, the BSS presents Bangladesh and China as two participants who are actively involved in the doing processes. The Bangladesh related participants are presented as goals, which are acted upon and affected in passive structures (headlines $2,10-15,24,26,28,47$ ) while the China related participants appearing as goals (headline 3, 7, 53).

Table 2: Material Process in the Headlines

\begin{tabular}{|c|c|c|c|c|}
\hline $\mathbf{H}$ & Date & Participant & Process & Participant \\
\hline 1 & $04 / 01 / 1977$ & Chairman Mao \{Actor & meets & Major General Ziaur Rahman \\
\hline 2 & 04/01/1977 & $\begin{array}{l}\text { Major general Ziaur Rahman's } \\
\text { speech }\{\text { Goal }\}\end{array}$ & [is delivered] & [by the speaker] \\
\hline 3 & 04/01/1977 & $\begin{array}{l}\text { Vice-Premier Li Hsien'nien's } \\
\text { Speech }\{\text { Goal }\}\end{array}$ & [is delivered] & [by the speaker \\
\hline 4 & $19 / 08 / 1982$ & PRC jute $\{$ Actor $\}$ & purchase & [from Bangladesh] \\
\hline 5 & $17 / 04 / 1987$ & Ershad $\{$ Actor $\}$ & visits & $\begin{array}{l}\text { Bangladesh-China Friendship Bridge } \\
\text { Sites }\end{array}$ \\
\hline 6 & $19 / 09 / 1987$ & PRC $\{$ Actor $\}$ & invites & Moazzem \\
\hline 7 & $01 / 10 / 1987$ & Embassy celebration $\{$ Goal $\}$ & [is held] & [by China] \\
\hline 8 & $25 / 12 / 1988$ & China, Bangladesh \{Actor\} & [is] to work & on flood control \\
\hline 9 & $19 / 06 / 1991$ & Papers $\{$ Actor $\}$ & report & on Zia's visit to PRC \\
\hline 10 & $19 / 06 / 1991$ & Dinner $\{$ Goal $\}$ & [is] hosted & [by China] \\
\hline 11 & $21 / 06 / 1991$ & 20 June activities $\{$ Goal $\}$ & [are reported] & [by the Media] \\
\hline 12 & 21/06/1991 & $\begin{array}{l}\begin{array}{l}\text { Visits Ming Qing Palace } \\
\text { \{Goal }\}\end{array} \\
\text { G }\end{array}$ & [are paid] & [ by the Prime Minister ] \\
\hline 13 & $21 / 06 / 1991$ & Protocol $\{$ Goal $\}$ & [is] signed & [by Bangladesh and China] \\
\hline 14 & $22 / 06 / 1991$ & 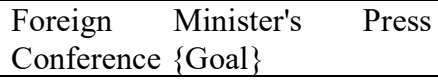 & [is held] & [by Bangladesh] \\
\hline 15 & 08/07/1991 & Flood Research Accord $\{$ Goal $\}$ & [is] signed & with PRC $\{$ Actor $\}$ \\
\hline 16 & $24 / 09 / 2003$ & BNP team $\{$ Actor $\}$ & reaches & China \\
\hline 17 & $17 / 8 / 2005$ & Bangladeshi MP \{Actor $\}$ & leaves & for China on official visit \\
\hline 18 & $22 / 10 / 2008$ & Bangladesh $\{$ Actor $\}$ & [is] to give & $\begin{array}{l}\text { full support to China in } \mathrm{UN} \text { to protect } \\
\text { rights of member countries }\end{array}$ \\
\hline 19 & $01 / 03 / 2010$ & China $\{$ Actor $\}$ & [is] to provide & support in building digital Bangladesh \\
\hline 20 & $17 / 03 / 2010$ & PM $\{$ Actor $\}$ & leaves & Dhaka for Beijing \\
\hline 21 & $17 / 03 / 2010$ & PM \{Actor $\}$ & arrives & in Beijing \\
\hline 22 & $16 / 06 / 2010$ & Chinese vice president $\{$ Actor $\}$ & places & wreath at national memorial \\
\hline 23 & $07 / 03 / 2011$ & Bangladesh: Russia \{Actor\} & edges out & $\begin{array}{l}\text { China in Hasina's quest for N-power } \\
\text { plant }\end{array}$ \\
\hline 24 & $03 / 01 / 2012$ & Deal $\{$ Goal $\}$ & [is] signed & $\begin{array}{l}\text { for 7th Bangladesh-China Friendship } \\
\text { Bridge }\end{array}$ \\
\hline 25 & $24 / 10 / 2012$ & Press $\{$ Actor $\}$ & reports & $\begin{array}{l}\text { Aid for trade: second general issues for } \\
\text { Bangladesh }\end{array}$ \\
\hline 26 & $29 / 04 / 2014$ & MOU $\{$ Goal $\}$ & [is] signed & $\begin{array}{l}\text { with China to set up } 1,320 \mathrm{MW} \text { coal- } \\
\text { fired plant }\end{array}$ \\
\hline 27 & $03 / 06 / 2014$ & PM $\{$ Actor $\}$ & [is] to visit & China on Friday \\
\hline 28 & $12 / 06 / 2014$ & $\begin{array}{l}\text { Bangladesh-China } \\
\text { statement }\{\text { Goal }\}\end{array}$ & [is held] & [by Bangladesh and China] \\
\hline 29 & $03 / 09 / 2014$ & China $\{$ Actor $\}$ & [is] to publish & book on Bangabandhu's visit \\
\hline 30 & $20 / 09 / 2014$ & Bangladesh $\{$ Actor $\}$ & maintains & outstanding relations with India, China \\
\hline 31 & $25 / 10 / 2014$ & Bangladesh $\{$ Actor $\}$ & joins & 21 countries in China-led Asian bank \\
\hline 32 & $09 / 01 / 2015$ & Chinese President $\{$ Actor $\}$ & $\begin{array}{l}{[\text { is }]} \\
\text { inaugurate }\end{array}$ & $\begin{array}{l}\text { construction of Karnaphuli tunnel: } \\
\text { Quader }\end{array}$ \\
\hline 33 & $02 / 02 / 2015$ & Chinese cultural show $\{$ Actor & begins & in City \\
\hline 34 & $06 / 05 / 2015$ & Chinese Premier $\{$ Actor $\}$ & [is] to visit & Dhaka in September \\
\hline 35 & $24 / 05 / 2015$ & Chinese Vice-Premier \{Actor $\}$ & arrives & [in Dhaka] \\
\hline 36 & $24 / 05 / 2015$ & Bangladesh, China $\{$ Actor $\}$ & sign & six instruments \\
\hline 37 & $26 / 05 / 2015$ & Chinese Vice-Premier \{Actor $\}$ & leaves & for home \\
\hline 38 & $19 / 06 / 2015$ & Bangladesh, China $\{$ Goal $\}$ & [is] to & by high-speed train \\
\hline
\end{tabular}




\begin{tabular}{|c|c|c|c|c|}
\hline & & & connected & \\
\hline 39 & $29 / 06 / 2015$ & Japan $\{$ Actor $\}$ & [is] to build & $\begin{array}{l}\text { deep-sea port at Matarbari, China at } \\
\text { Payera }\end{array}$ \\
\hline 40 & $28 / 07 / 2015$ & Chinese embassy $\{$ Actor $\}$ & hosts & reception on PLA anniversary \\
\hline 41 & $26 / 08 / 2015$ & China $\{$ Actor $\}$ & [is] to continue & $\begin{array}{l}\text { support to Bangladesh for economic } \\
\text { uplift }\end{array}$ \\
\hline 42 & $09 / 09 / 2015$ & $\begin{array}{l}\text { No alternative to socialism } \\
\text { AActor } \text { S }\end{array}$ & [is] to eliminate & discriminations: Inu \\
\hline 43 & $09 / 10 / 2015$ & BCFA $\{$ Actor $\}$ & [is] to celebrate & $\begin{array}{l}\text { 40th founding anniversary of BD- } \\
\text { China diplomatic ties }\end{array}$ \\
\hline 44 & $15 / 10 / 2015$ & Speaker $\{$ Actor $\}$ & meets & Chinese vice-president \\
\hline 45 & $26 / 10 / 2015$ & $\begin{array}{l}\text { Four Decades of Sino- } \\
\text { Bangladesh Relations }\{\text { goal }\}\end{array}$ & [are completed] & [in 2015] \\
\hline 46 & $10 / 10 / 2016$ & Exports to China $\{$ Actor $\}$ & increasing & [from Bangladesh]: Tofail \\
\hline 47 & $11 / 10 / 2016$ & 28 projects $\{$ Goal $\}$ & [are] finalized & [by China] \\
\hline 48 & $14 / 10 / 2016$ & Bangladesh $\{$ Actor $\}$ & rolls out & red carpet for Jinping \\
\hline 49 & $14 / 10 / 2016$ & Hasina, Xi \{Actor $\}$ & lay & foundation of tunnel, industrial zone \\
\hline 50 & $14 / 10 / 2016$ & JS speaker $\{$ Actor $\}$ & calls on & Chinese president \\
\hline 51 & $14 / 10 / 2016$ & Xi's visit $\{$ Actor $\}$ & lifted & $\begin{array}{l}\text { Dhaka-Beijing ties to "strategic } \\
\text { relationship" }\end{array}$ \\
\hline 52 & $15 / 10 / 2016$ & Jinping $\{$ Actor $\}$ & places & wreath at National Memorial \\
\hline 53 & $15 / 10 / 2016$ & Chinese President $\{$ Goal $\}$ & [is] given & hearty send off [by the Prime Minister] \\
\hline 54 & $15 / 10 / 2016$ & Bangladesh, China $\{$ Actor $\}$ & ink & \$13.6bn deals \\
\hline
\end{tabular}

Footnote-1: The curly brackets \{\} indicate the semantic roles of the participants or process types. The square brackets [] indicate an elided item. The third brackets ( ) indicates reference.

It can be seen from Table 2 that 38 actors are represented as what Fairclough (1995a, p. 39) calls "institutional subject", a term that refers to the participants. Of 17 place the Chinese participants as Actor, including "Chairman Mao" in 1, "PRC" in 4, 6, "China" in 19, 29, 41, "Chinese President" in 22, 32, "Chinese cultural show" in 33, "Chinese Premier" in 34, 35, 37, "Chinese embassy" in 40, "No alternative to socialism" in 42, "Exports to China" in 46 and "Jinping" in 51, 52. Of 13 place the Bangladeshi participants as Actor, including "Ersad" in 5, "BNP team" in 16, "MP" in 17, 20, 21, 27, "Bangladesh" in 18, 23, 30, 31, 48 and "Speaker" in 44, 50. Of 8 place the Sino-Bangladesh-related participants as Actor, including "Paper" in 9, "China, Bangladesh" in 8, "Press" in 25, "Bangladesh, China" in 36, 54, "Japan" in 39, "BCFA" in 43 and "Hasina, Xi" in 49. Table (2) also shows 16 goals as Subject in passive structure. Of 11 place the SinoBangladesh-related participants as Goal, including "dinner" in 10, "20 June activities" in 11, "protocol" in 13, " foreign Minister's press conference" in 14, "flood research accord" in 15, "deal" in 24, "MOU" in 26, " Bangladesh-China joint statement" in 28, "Bangladesh, China" in 38, "four decades of Sino-Bangladesh Relations" in 45 and " 28 projects" in 47 . Of 4 place the China related participants as Goal, including "VicePremier Li Hsiennien's speech" in 3, "Embassy celebration" in 7, "Visit Ming Qing Palace" in 12 and "Chinese President" in 53. Only one places Bangladesh as Goal, "Major general Ziaur Rahman's speech" in 2. The social subjects are expressed by the verb phrases that typically require animate subjects such as PRC invites in 6, Papers report in 9, Bangladesh [is] to give in 18, China [is] to provide in 19, Russia edges out in 23, Press reports in 25, China [is] to publish in 29, Bangladesh maintains in 30, Bangladesh joins in 31, Chinese embassy hosts in 40, China [is] to continue in 41, BCFA [is] to celebrate in 43, Bangladesh rolls out in 48 and Xi's visit lifted in 51. By connecting the social subjects with the actions of the verbs, the BSS seems to ally all the institutional subjects with "no alternative to socialism" to remove "discriminations" from two countries in 42 . After analysis of Actor and Goal in the material process, this study needs to analyze the mental process suggested by Halliday (1994, p. 117). Table (3) summarizes 42 mental processes with Sensor and Phenomenon appearing in the subject positions. Of 19 place the Bangladesh related participants as Sensor, including "outgoing Dhaka envoy" in 1, "Minister" in 6, "PM" in 9, 20, 21, 24, 26, 28, 37, "Bangladeshi politicians" in 10, "Dhaka" in 11, 40 , "Air Chief" in 12, "Proposed deep sea port in Bangladesh" in 14, Bangladesh" in 15, 23, "Hamid" in 22, "Speaker" in 29 and "President" in 39. Of 12 place the China related participants as Sensor, including "Chinese PM" in 7, "Better China-US ties" in 13, "China" in 16-18, 27, 32, "Yunnan governor" in 19, "Chinese Premier" in 25, "Chinese President Jinping" in 33, "Chinese Minister" in 38 and "Xi" in 41. Only 1 places the Sino-Bangladesh related participant as Sensor, "Bangladesh-China" in 34. Table (3) also shows 10 passive structures placing the Sino-Bangladesh-related participants as Phenomenon, including "PRC" in 2, "remark on trade" in 3, "curbing baby boom" in 4, "all possible help" in 5, "China's continued support to Bangladesh Army" in 8, "relations with China" in 30, 31, "friendship between Bangladesh and China" in 35, "China-Bangladesh" in 36 and 
"Bangladesh-China ties" in 42. By applying transitivity in the headlines, I need to look at the representations of the relational processes, which establish the power relations between the Material processes of the physical world and the Mental processes of the abstract world.

Table 3: Mental Processes in the Headlines

\begin{tabular}{|c|c|c|c|c|}
\hline $\mathbf{H}$ & Date & Participant & Process & Participant \\
\hline 1 & $18 / 08 / 1982$ & Outgoing Dacca Envoy $\{$ Sensor $\}$ & talks & with PRC leader \\
\hline 2 & $01 / 10 / 1987$ & PRC \{phenomenon $\}$ & [is] greeted & on national day, Dhaka celebration \\
\hline 3 & $19 / 06 / 1991$ & Remark on trade $\{$ phenomenon $\}$ & [is] questioned & [by Bangladesh] \\
\hline 4 & $21 / 06 / 1991$ & Curbing baby boom $\{$ phenomenon $\}$ & [is checked] & [by Bangladesh and China] \\
\hline 5 & $21 / 06 / 1991$ & All possible help \{phenomenon $\}$ & [is] assured & [by China] \\
\hline 6 & $07 / 05 / 1992$ & Minister $\{$ Sensor $\}$ & praises & PRC assistance to Army \\
\hline 7 & $13 / 01 / 2002$ & Chinese PM $\{$ Sensor $\}$ & $\begin{array}{l}\text { promises to } \\
\text { narrow }\end{array}$ & trade gap with Bangladesh \\
\hline 8 & $04 / 06 / 2002$ & $\begin{array}{l}\text { China's continued support } \\
\text { Bangladesh Army } \text { to } \\
\text { phenomenon }\end{array}$ & [is] assured & [by the speaker] \\
\hline 9 & $03 / 11 / 2003$ & PM $\{$ Sensor $\}$ & urges & $\begin{array}{l}\text { Chinese entrepreneurs to invest in } \\
\text { Bangladesh }\end{array}$ \\
\hline 10 & $11 / 04 / 2005$ & Bangladeshi politicians $\{$ Sensor $\}$ & term & Chinese MP's visit as significant \\
\hline 11 & $28 / 08 / 2005$ & Dhaka $\{$ Sensor $\}$ & sees & Beijing as core of Look East Policy \\
\hline 12 & $29 / 10 / 2009$ & Air Chief $\{$ Sensor $\}$ & apprises & $\begin{array}{l}\text { President of his upcoming China } \\
\text { visit }\end{array}$ \\
\hline 13 & $06 / 12 / 2009$ & Better China-US ties $\{$ Sensor $\}$ & will benefit & Bangladesh: Chinese envoy \\
\hline 14 & $21 / 03 / 2010$ & $\begin{array}{llll}\text { Proposed deep sea } & \text { port } & \text { in } \\
\text { Bangladesh }\{\text { Sensor }\} & & \\
\end{array}$ & will benefit & all neighbours: Hasina \\
\hline 15 & $22 / 03 / 2010$ & Bangladesh $\{$ Sensor $\}$ & plans & $\begin{array}{l}\text { deep sea port eying East, South } \\
\text { Asian neighbours }\end{array}$ \\
\hline 16 & $27 / 09 / 2011$ & China $\{$ Sensor $\}$ & rates & $\begin{array}{lll}\text { growing } & \text { Indo-Bangla } & \text { relations } \\
\text { 'positive' } & & \\
\end{array}$ \\
\hline 17 & $22 / 10 / 2012$ & China $\{$ Sensor $\}$ & wants to assist & BD facing climate risk \\
\hline 18 & $13 / 05 / 2014$ & China $\{$ Sensor $\}$ & seeks & $\begin{array}{l}\text { a new dimension of relations with } \\
\text { Bangladesh }\end{array}$ \\
\hline 19 & $08 / 06 / 2014$ & Yunnan governor $\{$ Sensor $\}$ & assures & $\begin{array}{l}\text { of promotion of trade with } \\
\text { Bangladesh }\end{array}$ \\
\hline 20 & $09 / 06 / 2014$ & PM $\{$ Sensor $\}$ & hopes & $\begin{array}{l}\text { new avenue of cooperation with } \\
\text { China }\end{array}$ \\
\hline 21 & $28 / 06 / 2014$ & PM $\{$ Sensor $\}$ & apprises & President of her Japan, China visits \\
\hline 22 & $08 / 11 / 2014$ & Hamid $\{$ Sensor $\}$ & seeks & more access to Chinese market \\
\hline 23 & $09 / 11 / 2014$ & Bangladesh $\{$ Sensor $\}$ & seeks & Chinese investment \\
\hline 24 & $22 / 04 / 2015$ & PM $\{$ Sensor $\}$ & holds & talks with leaders of five countries \\
\hline 25 & $07 / 05 / 2015$ & Chinese Premier $\{$ Sensor $\}$ & will visit & Dhaka in September \\
\hline 26 & $24 / 05 / 2015$ & PM $\{$ Sensor $\}$ & seeks & $\begin{array}{l}\text { more Chinese support for major } \\
\text { priority projects }\end{array}$ \\
\hline 27 & $25 / 05 / 2015$ & China $\{$ Sensor $\}$ & may benefit & $\begin{array}{l}\text { from BD's successful socio- } \\
\text { economic policies }\end{array}$ \\
\hline 28 & $09 / 06 / 2015$ & PM $\{$ Sensor $\}$ & hopes & $\begin{array}{l}\text { new avenue of cooperation with } \\
\text { China }\end{array}$ \\
\hline 29 & $12 / 06 / 2015$ & Speaker $\{$ Sensor $\}$ & seeks & $\begin{array}{l}\text { Chinese assistance for energy } \\
\text { sector }\end{array}$ \\
\hline 30 & $15 / 06 / 2015$ & Relations with China \{phenomenon\} & $\begin{array}{l}\text { will be } \\
\text { cemented }\end{array}$ & further in future: Syed Ashraf \\
\hline 31 & $16 / 06 / 2015$ & Relations with China \{phenomenon\} & $\begin{array}{l}{[\text { is } \text { to be }} \\
\text { cemented }\end{array}$ & further \\
\hline 32 & $25 / 08 / 2015$ & China $\{$ Sensor $\}$ & offers to invest & $350 \mathrm{~m}$ in various sectors \\
\hline 33 & $27 / 09 / 2015$ & Chinese President Jinping $\{$ Sensor $\}$ & $\begin{array}{l}\text { promises to } \\
\text { cut }\end{array}$ & trade deficit with Bangladesh \\
\hline 34 & $27 / 09 / 2015$ & Bangladesh-China $\{$ Sensor $\}$ & agreed to raise & Partnership to Newer Height \\
\hline 35 & $21 / 11 / 2015$ & Friendship between Bangladesh \& & be further & : Chinese Minister \\
\hline
\end{tabular}




\begin{tabular}{|l|l|l|l|l|}
\hline & & China \{phenomenon\} & cemented & \\
\hline 36 & $22 / 11 / 2015$ & $\begin{array}{l}\text { China-Bangladesh } \\
\text { \{phenomenon\} }\end{array}$ & $\begin{array}{l}\text { be further } \\
\text { cemented }\end{array}$ & , says Chinese minister \\
\hline 38 & $26 / 11 / 2015$ & PM \{Sensor\} & hopes & $\begin{array}{l}\text { getting China in Bangladesh's } \\
\text { development efforts }\end{array}$ \\
\hline 39 & $14 / 10 / 2016$ & President \{Sensor\} & $\begin{array}{l}\text { media campaign for enhanced } \\
\text { connectivity }\end{array}$ \\
\hline 40 & $15 / 10 / 2016$ & Dhaka \{Sensor\} & $\begin{array}{l}\text { duty \& quota-free entry of all } \\
\text { products into China }\end{array}$ \\
\hline 41 & $15 / 10 / 2016$ & $\begin{array}{l}\text { Xi \{Sensor\} } \\
\text { Seeks }\end{array}$ & eyes & $\begin{array}{l}\text { long-term ICT cooperation with } \\
\text { Beijing }\end{array}$ \\
\hline 42 & $16 / 10 / 2016$ & $\begin{array}{l}\text { Bangladesh-China } \\
\text { phenomenon }\end{array}$ & ties & Shinese support for development \\
\hline
\end{tabular}

Footnote 2: [The letter $(\mathrm{H})$ indicates "Headline" in all the Tables].

This study examines how the participants are classified as identifying and attributive in the relational process. In identifying process, the identified and the identifier (Halliday's (1994, p. 122) Token and Value) are used to identify each other. I shall first explain the relational process on the intensive type, ' $\mathrm{X}$ is $\mathrm{A}$ '. In this type, the most typical verb is 'be' while $X$ and A are nominal groups. Tables (4-5) have included 44 relational processes with Carrier and Attribute according to Halliday (1994, p. 130). Table (4) illustrates 17 Carriers appearing in the subject positions: Of 8 place the Bangladesh related phrases as Carrier with "MP's" in 2, "AL" in 6, "PM" in 7, 8, 9, 10, "President Abdul Hamid" in 12, 13. Of 6 place the China related phrases as Carrier with "Message" in 3, 4, "talks" in 5, "Beijing" in 11 and "six member Chinese delegations" in 16. Of 3 delete Bangladesh and China from Carrier, including "new development" in 1, "major FDI boost" in 15 and "global economy" in 17. Table (4) also shows 17 circumstantial elements at the end of the clause. Of 10 place the SinoBangladesh related phrases as Circumstance, including "in China-Bangladesh relations" in 1, "for further development of communication between China, Bangladesh" in 6, "for increasing Chinese investment in Bangladesh" in 7, "for direct road, rail links with China" in 8, "for strong ties with China" in 9, 10, "for new height in ties with Dhaka" in 11, "for reducing Bangladesh-China trade gap" in 13, "for taking Dhaka-Beijing relations to new heights" in 14 and "in precarious state" in 17. Of 6 place the China related phrases as Circumstance, including "to PRC" in 2, "to Li" in 3, "to Zhao" in 4, "with Li" in 5, "in Beijing" in 12, "from China on the way" in 15. Only 1 places the Bangladesh related phrase as Circumstance, "in city" in 16.

Table 4: Circumstances in the Headlines

\begin{tabular}{|l|l|l|l|l|}
\hline H & Date & Carrier & Process & Circumstance \\
\hline 1 & $06 / 01 / 1977$ & New development & {$[$ is $]$} & in China-Bangladesh relations \\
\hline 2 & $21 / 09 / 1987$ & MP's & {$[$ is $]$} & to PRC \\
\hline 3 & $01 / 10 / 1987$ & Message & {$[$ is $]$} & to Li \\
\hline 4 & $01 / 10 / 1987$ & Message & {$[$ is $]$} & to Zhao \\
\hline 5 & $20 / 06 / 1991$ & Talks & {$[$ are $]$} & with Li \\
\hline 6 & $05 / 12 / 2009$ & AL & {$[$ is $]$} & $\begin{array}{l}\text { for further development of communication } \\
\text { between China, Bangladesh }\end{array}$ \\
\hline 7 & $19 / 03 / 2010$ & PM Hasina & {$[$ is $]$} & for increasing Chinese investment in Bangladesh \\
\hline 8 & $20 / 03 / 2010$ & PM & {$[$ is $]$} & for direct road, rail links with China \\
\hline 9 & $12 / 12 / 2011$ & PM & {$[$ is $]$} & for strong ties with China \\
\hline 10 & $12 / 12 / 2011$ & Bangladeshi PM & {$[$ is $]$} & for strong ties with China \\
\hline 11 & $12 / 05 / 2014$ & Beijing & {$[$ is $]$} & for new height in ties with Dhaka \\
\hline 12 & $08 / 11 / 2014$ & President Abdul Hamid & {$[$ is $]$} & in Beijing \\
\hline 13 & $02 / 02 / 2015$ & President & {$[$ is $]$} & for reducing Bangladesh-China trade gap \\
\hline 14 & $25 / 05 / 2015$ & China & {$[$ is $]$} & for taking Dhaka-Beijing relations to new heights \\
\hline 15 & $19 / 06 / 2015$ & Major FDI boost & {$[$ is $]$} & from China on the way: FBCCI president \\
\hline 16 & $25 / 11 / 2015$ & $\begin{array}{l}\text { Six member Chinese } \\
\text { delegation }\end{array}$ & {$[$ is $]$} & in City \\
\hline 17 & $16 / 10 / 2016$ & Global economy & {$[$ is $]$} & in precarious state, Xi tells BRICS summit \\
\hline
\end{tabular}

Table (5) shows 13 possessive processes as a nominal group formulated by Halliday (1994, p. 133). It can also be seen from Table (5) that the ideological relations are constructed with the ownership of social subjects and their words, which are "Bangladeshi products" and "duty free access to China" in 1 and "China" and "full assistance to achieve goals of Vision 2021, 2041" in 11. In addition, the rhetorical relation between "Dhaka- 
Beijing Agree" and "cooperation to newer height" in 5 and "China" and "Bangladesh" in 7-9 has reinforced Sino-Bangladesh relations stronger. Their reality shows "Water availability" with "Himalayan river basins" in 2 , "China" with "develop road and rail communication" in 12. In a wider sense, "Chinese policy" is assigned with "economic ties with neighbours" in 4 , which increase the regional relations. China recognizes "Bangladesh becomes middle income country by 2021 " in 3 . Thus in 10 "China is Bangladesh's inspiration to achieve middle-income status", whereas China is the Token and Bangladesh's is the Value.

Table 5: Possessive Processes in the Headlines

\begin{tabular}{|l|l|l|l|l|}
\hline H & Date & Possessor & Possession & Possessed \\
\hline 1 & $18 / 03 / 2010$ & Bangladeshi products & {$[$ is] to get } & duty free access to China \\
\hline 2 & $17 / 06 / 2010$ & $\begin{array}{l}\text { Water availability per } \\
\text { capital }\end{array}$ & {$[$ is] to decline } & in Himalayan river basins \\
\hline 3 & $21 / 10 / 2012$ & China & {$[$ is] to help } & $\begin{array}{l}\text { Bangladesh become middle income } \\
\text { country by 2021 }\end{array}$ \\
\hline 4 & $06 / 06 / 2014$ & Chinese policy & {$[$ is] to accelerate } & economic ties with neighbours: PM \\
\hline 5 & $11 / 06 / 2014$ & Dhaka-Beijing agree & {$[$ is] to extend } & cooperation to newer height \\
\hline 6 & $14 / 06 / 2014$ & China visit & {$[$ is] to deepen } & relation: PM \\
\hline 7 & $28 / 12 / 2014$ & Wang: China & {$[$ is] to remain beside } & Bangladesh \\
\hline 8 & $28 / 12 / 2014$ & China & {$[$ is] to remain beside } & Bangladesh: Wang \\
\hline 9 & $13 / 01 / 2015$ & Wang: China & {$[$ is] to remain beside } & Bangladesh \\
\hline 10 & $02 / 04 / 2015$ & China & is & $\begin{array}{l}\text { Bangladesh's inspiration } \\
\text { middle-income status: FM }\end{array}$ \\
\hline 11 & $25 / 05 / 2015$ & China & $\begin{array}{l}\text { full assistance to achieve goals of Vision } \\
\text { 2021, 2041 }\end{array}$ \\
\hline 12 & $29 / 10 / 2015$ & China & [is] to extend & $\begin{array}{l}\text { develop road \& rail communications } \\
\text { change socio-economic scenario in Asian } \\
\text { region }\end{array}$ \\
\hline 13 & $27 / 01 / 2016$ & BCIM-EC & {$[$ is] to help } & \\
\hline
\end{tabular}

Table (6) shows 14 intensive processes, whereas the Subject is the identified/Token and the rest is the identifier/Value (Halliday, 1994, p. 124). China is the Token which promotes 5 positive values such as "tested friend of Bangladesh" in 3, "eager to be partner of building digital Bangladesh" in 7, "keen to ink FTA to cut trade deficit" in 8, "keen to provide financial assistance to Bangladesh" in 13 and "keen to scale up investments" in 14. Chinese FM is the Token carrying Value with "Saturday" in 5 and "Today" in 6. Bangladesh is the Token which promotes 3 positive values such as "a strategic partner of China" in 4, "a middle income nation by 2021" in 11, 12 and "PM" is the Token "maintaining good ties with neighbours" as Value in 9. Only 2 tokens are constructed with the values as "Bangladesh" in 1, "science minded" in 2. Furthermore, the BSS categorizes India, along with China as a Token and "epoch making" as a Value in 10. Table (6) also brings together in a single display all the categories of relational processes, where the Subject, in the column of the Token/identified is constructed by the Finite along with circumstance in the mood structure. Therefore, the BSS writers have constructed Sino-Bangladesh relations both syntactically and thematically.

Table 6: Intensive in the Headlines

\begin{tabular}{|l|l|l|l|l|}
\hline H & Date & Identified/Token & Intensive & Identifier/Value \\
\hline 1 & $21 / 06 / 1991$ & Canal digging & {$[$ is $]$} & {$[$ [necessary in Bangladesh] } \\
\hline 2 & $23 / 06 / 2002$ & Encourage Youths & {$[$ is] to be } & science minded: PM \\
\hline 3 & $16 / 06 / 2010$ & China & {$[$ is $]$} & tested friend of Bangladesh: Speaker \\
\hline 4 & $10 / 06 / 2014$ & Bangladesh & {$[$ is] } & a strategic partner of China: Xi \\
\hline 5 & $23 / 12 / 2014$ & Chinese FM & {$[$ is $]$} & due on Saturday \\
\hline 6 & $27 / 12 / 2014$ & Chinese FM & {$[$ is $]$} & due today \\
\hline 7 & $28 / 12 / 2014$ & China & {$[$ is $]$} & $\begin{array}{l}\text { eager to be partner of building digital Bangladesh: } \\
\text { Chinese FM }\end{array}$ \\
\hline 8 & $29 / 12 / 2014$ & China & {$[$ is] } & keen to ink FTA to cut trade deficit \\
\hline 9 & $15 / 06 / 2015$ & PM & {$[$ is $]$} & keen on maintaining good ties with neighbours \\
\hline 10 & $01 / 09 / 2015$ & Bangladesh's relations & {$[$ is] } & Epoch-making: Inu \\
& & with China, India & {$[$ is] to be } & a middle-income nation by 2021- global report \\
\hline 11 & $25 / 09 / 2015$ & BD & {$[$ is] to be } & middle-income nation by 2021: report \\
\hline 12 & $27 / 09 / 2015$ & Bangladesh & {$[$ is] } & keen to provide financial assistance to Bangladesh \\
\hline 13 & $19 / 11 / 2015$ & China & {$[$ are] } & keen to scale up investments \\
\hline 14 & $27 / 11 / 2015$ & Chinese entrepreneurs & Finite & Circumstance \\
\hline & & Subject &
\end{tabular}




\begin{tabular}{|l|l} 
Mood & Residue
\end{tabular}

\section{Conclusion}

The findings show how the social subjects are constructed through the BSS media discourse of Sino-Bangladesh relations. Chapter four explained that the media representation in the headlines of the social subjects generally reflects social practice, ideology and power relations in social structures at the time of reporting. Using Halliday's transitivity system, this analysis has found how the English clause is combined with three functional components (called 'metafunctions'), which are the representations of Bangladesh and China as two participants, Actor and Goal in the Material; Sensor and Phenomenon in the Mental; and Carrier and Attribute in the Relational processes (Token as Subject). The systems are the mix of the configurations among the types of processes, participants and circumstances. By using 140 news headlines, the BSS must try to reflect its audiences towards the Sino-Bangladesh relations. This study has pointed out 55 participants as China, 46 participants as Bangladesh and 39 participants as Sino-Bangladesh relations appearing at the subject position. Representations of the participants as social subject not only encode the evaluation and judgment but also create an opposition between us (Bangladesh) and them (China) and construct a world of 'ideology' that must remove discriminations from both countries. Part four detailed the representations of Bangladesh and China as two dominant actors constructed with use of personal terms in understanding how ideologies reside in texts and language is a material form of ideology (Fairclough, 1995a, p. 73). The actors can be represented linguistically in various ways. Name reference is a key device in understanding the representation of the actors to the readers of the headlines. 'Chairman Mao' and 'Xi' are two historical figures appearing in the clause as a representation. The people with extreme beliefs on particular meanings seem to demand that the complexity is inherent in many headlines, where power is often associated with the act of controlling the non powerful participants (Renugah, 2015, p. 63). CDA balances the emphasis on the text with the careful examination of media discourse practices, although the BSS looks for newswire stories that are 'copy ready'. This article, however, is a step towards the examination of media discourse which is not limited to the text and talk but accounts also for their functions (van Dijk, 2005, p. 66). CDA provides analysts with the tools to explain the structures of social and political contexts within media discourse, which has the power to influence social relations, social subjects and identities (Fairclough, 1995b, p. 2). Therefore, CDA calls solidarity between Bangladesh and China with the establishment of diplomatic ties in the October 1975, which is the main actor of making Sino-Bangladesh relations stronger. As we celebrate the $43^{\text {th }}$ anniversary of Sino-Bangladesh relations in the October 2018, the historical review will fill us with confidence and expectations to our two nations, who will join hands and move forward in constructing the old trusted friendship. Analysis of the media representations reveals the ideational meaning of social subjects and their actions within contexts of Sino-Bangladesh relations, which will be benefited in many ways. This study covers the BSS media discourse, which was limited to the analysis of news headlines. Another limitation is the news body, which was excluded from the analysis if these relations will develop more, many issues will include with this relation in future.

\section{Acknowledgements}

First and foremost, I am greatly acknowledged to the School of International Exchange of the Shanghai University and the Shanghai Government Scholarship Authority for their support to undertake my PhD degree in 2015. Furthermore, I am indebted to Tang Qingye, Supervisor and Professor of discourse analysis at the School of Foreign Languages for her lectures (November 2015-March 2016). Finally, I am grateful to the BSS journalists in Dhaka for their cooperation to collect data on this topic (June 2016- October 2017).

\section{References}

Ahmed, SM. S. (Ed.). (2013) Bangladesh-China relations: Scopes for attaining new heights. BIISS Journal, 34(4), pp. 273-292.

Allan, John Andrew. (2013) The Cambridge Shorter History of India, Literary Licensing, p. 145.

Bloomfield, L (1933) Language, New York: Holt.

Bangladesh. (1988) Early history (1000 B.C.-A.D. 1202). Bangladesh: A country study. Washington, D.C.: Library of Congress. September 1988.

Bell, A. (1991) The Language of News Media, Oxford: Blackwell.

Bell, A. (1999) News Stories as Narratives, in A. Jaworski and N. Coupland (Eds.).

Bell, A and Garrett, P. (1998) Media and Discourse: A Critical Overview, in A. Bell and P. Garrett (ed.) Approaches to Media Discourse, Oxford: Blackwell, pp.1-20.

Bangladesh Country Assessment (2003) Country Information \& Policy Unit, IMMIGRATION AND NATIONALITY DIRECTORATE: United Kingdom, pp. 1-35.

Begum, Anwara. (2015) Sino-South Asian Relations: Missed Opportunities, Dhaka: AHDPH.

BD-China Embassy. (2017) Dhaka, Bangladesh, [online], available: http://bd.china-embassy [accessed 20 October 2017]. 
Cochrane, C., N. (1929) Thucydides and the Science of History, Oxford: Oxford University Press, p. 179.

Chomsky, N. (1957) Syntactic Structure, The Hague: Mounton.

Chomsky, N. (1965) Aspects of the theory of Grammar, MIT press.

China Brief (2009) Journal of Analysis and Information, Jamestown foundation, 9 (15), July 23, p. 10.

China and South-South Scoping Assessment for Adaptation, Learning and Development (CASSALD). (2013) Appendix II: Bangladesh Country Report, January 2013, pp. 1-81.

Chandra, V. (2015) India and South Asia: Exploring Regional Perceptions, Institute for Defense Studies and Analyses: New Delhi.

Data, S. (2008) Bangladesh's Relations with China and India: A Comparative Study, Strategic Analysis, 32(5), pp. 755-772.

Foucault, M. (1972) The Archaeology of Knowledge (translation by A M Sheridan Smith), London: Tavistock.

Foucault, M. (1980) Power-knowledge: Selected Interviews and Other Writings (1972-1977), Colin Gordon (ed.), Pantheon Books: New York.

Fowler, R. (1994) Language in the News. London: Routledge.

Fairclough, N. (1989) Michel Foucault and the Analysis of Discourse, Centre for Language in Social life Research Paper 10, Lancaster University.

Fairclough, N. (1992) Discourse and social change, Cambridge: Polity press.

Fairclough, N. (1995a) Critical Discourse Analysis: The Critical Study of Language, London: Longman.

Fairclough, N. (1995b) Media Discourse, London: Edward Arnold.

Fairclough, N. (2001) Language and Power, London: Longman.

Fairclough, N. (2003) Political Correctness: the Politics of Culture and Language, Discourse \& Society, 14 (1), pp. 17-28.

Frantz, R. S. (2006) The Linguistic Constructions of Agency and Identity in Gay VS. Mainstream media coverage of same sex marriage: A critical discourse approach, UMI 3237083, ProQuest LLC 2007: USA.

Gramsci, A. (1971) Selections from the Prison Notebooks In Q.Hoare and G. Nowell Smith (eds.), Lawrence \& Wishart.

Glass, D. (2001) The Global Flow of Information: A Critical Appraisal from the Perspective of Arab-Islamic Information Sciences, in K. Hafez (ed.) Mass Media, Politics, and Society in the Middle East, Cresskill, NJ: Hampton Press, pp. 217-40.

Habermas, J. (1984) The Theory of Communication Action, Vol.1. Heinemann.

Hall, S. (1985) Signification, Representation, Ideology: Althusser and the Post Structural Debates, Critical Studies in Mass Communication, 2, pp. 91-114.

Halliday, M.A. R. (1994) An Introduction to Functional Grammar, $2^{\text {nd }}$ Ed, London: Edward Arnold.

Islam, N., I. and Askari, M., M., R. (2015) Belt and Road Initiative of China: A new hope in the Region, Bangladesh Journal of Tariff and Trade, 4, October-December, 2015.

Keay, John (2011) India: A History, ISBN 0-8021-4558-2: Grove Press, pp. 220.

Malinowski, B. (1923) The Problem of Meaning in Primitive Languages, Supplement 1. In C. Ogden and I. A. Richards the Meaning of Meaning, New York: Harcourt Brace.

Ministry of Information. (2008) Law \& regulation publication: Bangladesh Sangbad Sangstha (BSS), Dhaka: Ministry of Information, pp. 469-527.

Ministry of Foreign Affairs. (2017) Annual performance of Bangladesh, July 1, (pp 3-24), [online], available: http:// www.moi.gov.bd.com [accessed 21 October 2017].

Pandey, N. (2013) China in South Asia: Future Possibilities (BM Kabir ed.), Sino-South Asian Relations, University of Chittagong, pp. 57-68.

Parlene, A. (2013) Importance of the Free Trade Agreement between Bangladesh and China (BM Kabir ed.), Sino-South Asian Relations, University of Chittagong, pp. 280-314.

Robert, R. (1987) The Languages of China. Princeton: Princeton University Press.

Rashid, H. ur. (2010) Bangladesh Foreign Policy: Realities, priorities and challenges. Dhaka: Academic Press and Publishers Library (APPL).

Roca, T. (2013) Human Development Report, The Rise of the South, Human Progress in a Diverse World. Afriquecontemporaine, 246(2), pp. 164.

Renugah Ramanathan, B. H. Tan . (2015) Application of Critical Discourse Analysis in Media Discourse Studies, the Southeast Asian Journal of English Language Studies, 21(2), pp. 57-68.

Singh, Prashant Kumar. (2010) China-Bangladesh Relations: Acquiring a Life of their Own, China Report 2010, Institute of Chinese Studies: New Delhi.

Sarker, Noor Mohammad. (2014) Bangladesh-China Relationship at the Dawn of the Twenty first Century, Peace and Security Review, 6 (11), pp. 72-96.

U N E S C O. (1953) News Agencies, Structure and operation, UNESCO, Gorges Lang, Paris, France YC.52.D.1tlA. 
Uddin, A.G.M, N. (2013) Political Dimensions of Sino-Bangladesh Relations: Recent Trends (BM Kabir ed), Sino-South Asian Relations, University of Chittagong, pp. 230-241.

Van Dijk, T. (1988) News as Discourse. Erlbaum.

Van Dijk, T. (1993) Principles of Critical Discourse Analysis, Discourse Society, 4 (2), pp. 249-283.

Van Dijk, T. (2005) War Rhetoric of a Little Ally: Political Implicatures and Aznar's legitimatization of the War in Iraq, Journal of language and politics, 4 (1), pp. 65-92.

Williams, R. (1981) Culture, London: Fontana.

Wodak, R. (1989) Language, Power and Ideology, Studies in Political Discourse, Amsterdam: Benjamins.

Xianyi, Z. (2010) History and Legend of Sino-Bangla Contacts, Embassy of China to Bangladesh: Dhaka.

Yasinbin . (2012) China Bangladesh Relation, Discussion in Bangladesh Defense Forum.

Zhang, M. (2014) A critical Discourse Analysis of Political News Reports, Theory and Practice in Language Studies, 4(11), pp. 2273-2277.

Corresponding Author: MUHAMMAD ANISUR RAHMAN AKANDA is a lecturer, Department of English, Govt. Haji Jalmamud College, Nakla, Sherpur, Bangladesh and a $\mathrm{PhD}$ candidate, specialized in the major of culture, language and world civilization at Shanghai University in China. His research interest is in critical discourse analysis, semantics and language acquisition. ADDRESS: School of Foreign Languages, Shanghai University, 99 Shangda Road, Bhaoshan district, Shanghai, 200444, China. 